\title{
Career Breakthroughs of Women in Intercollegiate Athletic Administration: What is the Role of Mentoring?
}

\author{
Meg G. Hancock \\ University of Louisville
}

Heidi Grappendorf

University of Cincinnati

\author{
Janelle E. Wells \\ University of South Florida
}

\author{
Laura J. Burton \\ University of Connecticut
}

\begin{abstract}
Participation in mentoring is integral for advancement within sport organizations, particularly for women (Bower, 2009; Shaw, 2006). However, it is unclear how mentoring contributes to opportunities for career advancement or breakthroughs (e.g., opportunities for new functional roles, project oversight) (Mainiero, 1994). Therefore, the purpose of this study was to understand the role of mentoring as it pertains to career breakthroughs for women in intercollegiate athletic administration. This qualitative study included 51 focus group participants in athletic administration at NCAA-member institutions (divisions, I, II, and III). Results suggested mentoring as a critical factor in career advancement. Participants indicated having a mentor was highly desired. Mentoring relationships with someone internal and external to their respective athletic departments was important. However, there was little consensus on the benefits or drawbacks of having a mentor of the same or opposite sex. Implications and strategies for developing mentoring relationships are also discussed.
\end{abstract}

Keywords: mentoring, career breakthrough, intercollegiate athletics, women

\footnotetext{
Hancock is with the Department of Health and Sport Sciences University of Louisville, Louisville, Kentucky. Grappendorf is with the School of Human Services, University of Cincinnati, Cincinnati, Ohio. Wells is with the Department of Sport Management, University of South Florida, Tampa, Florida. Burton is with the Department of Educational Leadership, University of Connecticut, Storrs, Connecticut. Address author correspondence to Meg Hancock at meg.hancock@louisville.edu.
} 
Women comprise $22.3 \%$ of Athletic Directors across three National Collegiate Athletic Association (NCAA) divisions (Acosta \& Carpenter, 2014). While the percentages indicate that intercollegiate athletic administration is a male-dominated occupation (United States Department of Labor, 2014), organizational structures of sport organizations appear less hierarchical and more inclusive of women than ever before (Lapchick, 2016a, 2016b, 2016c). The subtle shift in structure could reflect that traditionally male-dominated industries and occupations, such as those in sport, now "value talent over gender and offer a more level playing field" (Eagly \& Carli, 2003, p. 827) for women seeking top management positions. For example, segments of the professional sport industry have shown more emphasis and progress in hiring and advancing women (Lapchick, 2016a, 2016b, 2016c). Yet, while more women work in college athletics than ever before (Acosta \& Carpenter, 2014), recent statistics show that college athletic departments "remain the worst employer for women" (Lapchick, 2017, para. 2) when compared with other sport industry segments.

Sport management scholars argue that the male-dominated structure of intercollegiate athletic administration reflects an industry in which men and men's activities are valued and rewarded (Cunningham, 2008; Knoppers, 1992). That is, men may be more likely to advance through the administrative ranks of a college athletic department even when a woman is equally qualified for such advancement (Burton, Barr, Fink \& Bruening, 2009; Burton, Grappendorf, $\&$ Henderson, 2011). Moreover, the male-dominated nature of intercollegiate athletics has been identified as a contributing factor to the dearth of women in athletic administration. Specifically, male-dominated organizational structures are perceived to contribute to gender and gender stereotyping, discriminatory hiring practices, and limited opportunities for skill development; thus, limiting the career advancement of women in athletic departments (Aicher \& Sagas, 2009; Burton et al., 2009; Burton et al., 2011; Hoffman, 2011; Hancock \& Hums, 2015). Conversely, collegial support, networking, and mentoring foster career tenure in sport organizations (Bower, 2009; Hancock \& Hums, 2016; Shaw, 2006). As such, participation in mentoring relationships has been suggested by these studies as integral for women's advancement in intercollegiate athletic administration. In addition, mentoring may aid in career interest and tenure thereby resulting in more female role models, higher proportions of women working in intercollegiate athletic administration, and a greater likelihood of women mentoring other women (Bower \& Hums, 2013).

While mentoring relationships are important for women in intercollegiate athletic administration (see Bower \& Hums, 2013), it is unclear as to how mentoring contributes to opportunities for advancement known as career breakthroughs (Mainiero, 1994; Ohlott, Ruderman, \& McCauley, 1994). Career breakthroughs may offer opportunities for new functional roles, project oversight, and/or more organizational power (Metz \& Tharenou, 2001). However, it has been noted that women in male-dominated industries often receive less support, and their efforts are often scrutinized more critically, making it of the utmost importance to examine mentoring and how it contributes to career breakthroughs (Kanter, 1977; Walker $\&$ Sartore-Baldwin, 2013). Therefore, the purpose of this study was to understand the role of mentoring as it pertains to career breakthroughs for women in intercollegiate athletic administration. 


\section{Literature Framework}

Before we discuss the relevant mentoring literature, it is important to examine the environment in which women are seeking to advance their careers. As noted above, women receive less support and are under greater scrutiny in male-dominated organizations. Though there may be a shift toward more women in college athletics administration, men are still overrepresented in the most senior level positions (Lapchick, 2017). In addition, sport organizations operate in a gendered space, as sport is used to "actively construct boys and men to exhibit, value and reproduce traditional notions of masculinity" (Anderson, 2009, p. 4).

When discussing women's career development in sport organizations, we must consider how gender works as both an organizational and social process (Connell, 2009). Gender can influence organizational practices, as images, cultures, interactions, and gender-appropriate behaviors are linked to socially constructed masculine or feminine ideals in how an organization operates (Britton \& Logan, 2008). As noted by Kihl and colleagues, it is important to understand gender as a social process because it helps to explain how and why gender is such a powerful factor in the social and organizational processes within sport organizations (Kihl, Shaw, \& Schull, 2013). Therefore, when considering the influence of mentoring in college athletic administration, we must account for how gender influences this process.

\section{Mentoring}

From Fortune 500 companies (Bryant, 2015) to professional development organizations in intercollegiate athletics (NACDA, 2016a, 2016b), interest in mentoring relationships continues to grow. Not surprisingly then, mentoring relationships and their outcomes are oft-studied phenomena in career development and management literature (Baranik, Roling, \& Eby, 2010; Bozionelos, Bozionelos, Kostopoulos, \& Polychroniou, 2011; Boddy, Agllias, \& Gray, 2012; Eshner, Thomas, \& Murphy, 2001; Kram, 1983; Ragins, 1997). Though a myriad of definitions on mentoring exist, for this study, the mentor relationship is defined as, "A network of individuals with equal or greater experience than the protégé who can be a positive role model and provide emotional and career support" (Eshner et al., 2001, p. 421).

The relationship between a mentor and protégé consists of support, guidance, and counseling, and has the potential to "enhance career development and psychosocial development of both individuals" (Kram, 1983, p. 613). Thus, mentors provide two distinct, but related functions for protégés - career and psychological (Kram, 1985). Career functions prepare the protégé for advancement and may include career advice, access to networks, and professional protection. Psychological functions include building a protégé's sense of professional self, providing a sounding board and problem-solving strategies, giving respect and support, and role modeling.

Mentors may exist internal or external to the organization. Internal mentors are individuals employed in the same organization as their protégé, while external mentors are employed by a different organization than their protégé (Baugh \& Fagenson-Eland, 2005). For this study, we extended the definition of an external mentor to someone who works outside of the intercollegiate athletic department, but may still be employed by the same college or university. Thus, mentoring can occur between a mentor and protégé in an athletic department (internal) or between 
a mentor and protégé outside the athletic department (external). Understanding the advantages and disadvantages to internal and external mentorship may provide a more beneficial experience for both the mentor and protégé, including more opportunities for career breakthroughs.

Chao (1998) argued that internal mentors are particularly helpful when a protégé seeks advancement in the same organization. Internal mentors may also (a) have access to more organizational resources; (b) be more physically accessible than external mentors; (c) provide assignments and feedback to enhance protégé self-confidence; (d) offer protection to protégés in adverse organizational environments (Ragins, 1997). Further, protégés with internal mentors reported higher levels of career and psychological support than protégés with external mentors (Baugh \& Fagenson-Eland, 2005). Conversely, internal mentors may not be the best choice if a protégé wishes to gain visibility in their profession, not just the organization, or if a protégé has geographic mobility and seeks a move (Baugh \& Fagenson-Eland).

External mentors may be viewed as an objective sounding board for protégés that seek advice or problem-solving strategies from a different perspective. In addition, external mentors can offer extended professional networks, which may be beneficial for career mobility (Baugh \& Fagenson-Eland, 2005; Ragins, 1997). Protégés with external mentors may be more independent and have greater self-efficacy because mentors are not immediately available for guidance (Baugh $\&$ Fagenson-Eland, 2005). On the contrary, external mentors, even with technological advances, may have less face-to-face contact; thus, developing a trusting relationship between the external mentor and protégé may prove difficult (Baugh \& Fagenson-Eland).

Addressing considerations related to both internal and external mentoring, the goals of the mentoring relationship are important to consider. Eshner and colleagues (2001) suggested protégés need to develop a network of mentoring relationships. The network of mentors represents a constellation of relationships that offer developmental support to an individual (Kram, 1985). Specifically, the constellation is "a set of relationships an individual has with people who take an active interest in and action to advance the individual's career assisting with his or her personal and professional development" (Higgins \& Thomas, 2001, p. 224). As a developmental approach, constellation mentoring differs from traditional mentoring constructs (e.g., hierarchical, focused on learning of the protégé, single dyadic relationship typically within a single organization) in that it occurs within and across organizations, and with individuals at various organizational levels (Higgins \& Kram, 2001). In addition, constellation mentoring is characterized by mutuality and reciprocity of professionals in the mentoring network.

Constellation mentoring is particularly important for women working in the gendered space of a sport organization as they are likely to face complex barriers to career progression in college athletic administration (Burton et al., 2009, 2011; Hoffman, 2011; Hancock \& Hums, 2015). The varied perspectives and experiences shared by mentors in a constellation network are likely to help women anticipate and navigate the myriad challenges they may encounter in the work place. In the sport context, Kelly and Dixon (2014) suggested constellation mentoring as a framework for addressing the needs of African American male student-athletes in their transition to college. Constellation mentoring was identified as a critical component to helping African American male student athletes contend with challenges 
(e.g., stereotypes; economic and educational disparities; athletic expectations) in the college environment.

Furthermore, a network, or constellation, of mentors also allows for greater accessibility to a variety of mentors, rather than a single dyadic relationship found in traditional mentoring (Eshner, et al., 2001). For example, Young and Perrewe (2000) suggested it is important to consider time limitations in that mentors often have multiple time constraints and responsibilities; they may also mentor more than one protégé. While women may be less likely to mentor other women because they are not proportionally represented in administrative ranks (Dworkin, Maurer, \& Schipani, 2012), women may still seek other women as mentors. This, however, may over-burdened women in upper management with the perceived expectations and responsibilities of mentoring younger women (Cullen \& Luna, 1993; Ritchie et al., 1997). Therefore, when women access a constellation of mentors, rather than a singular mentor, this may alleviate the burden felt by women in higher levels of management.

Mentors are critically important to the career growth and development of women pursuing careers in intercollegiate athletics as they can offer guidance and assistance as women seek to overcome challenges (e.g., gender stereotyping, discriminatory hiring practices, limited opportunities for skill development) and progress through athletic administration hierarchies. Similarly, mentors may provide a conduit to job and career opportunities, which have the potential to translate to career growth, advancement, and other positive outcomes.

\section{Mentoring Outcomes for Protégés}

Given the developmental nature of the mentor/protégé relationship, mentoring affords the protégé certain outcomes. Protégés often benefit from tangible and objective outcomes of mentoring such as higher rates of promotion (Allen, Eby, Poteet, Lentz, \& Lima, 2004; Eshner et al., 2001; LaPierre \& Zimmerman, 2012) and higher salaries and bonuses (Allen et al., 2004; Burke \& McKeen, 1996; Ramaswami, Dreher, Bretz, \& Wiethoff, 2010). Promotions and higher salaries are often measures of career success (Allen et al., 2004), but perhaps a less tangible and more subjective outcome often attributed to career success is career satisfaction. For example, studies have shown that when protégés are more satisfied with their respective careers (Burke \& McKeen, 1996; Ramaswami et al., 2010), they are more likely to believe in their ability to advance and feel more competent and effective in their work (Singh, Ragins, \& Tharenou, 2009a). Mentoring has also helped women gain a greater understanding of self, including how they operate within an organization, and the ways they might need to adapt to gain more opportunities for career success (Ibarra, Carter, \& Silva, 2010). In addition, women satisfied with their careers exhibit higher rates of organizational commitment (Allen et al., 2004), an important positive outcome related to lower turnover intentions (Baranik et al., 2010). Finally, Fagenson (1989) noted that protégés can also gain more power within an organization. However, much of the evidence linking mentoring to positive career outcomes has examined the outcomes for male protégés (Ragins, 1997).

Recent research on the careers of women suggests that building a relationship with a mentor is an important and effective way for women to reach top management levels (Baumgartner \& Schneider, 2010; Dworkin et al., 2012). As Bower 
(2009) noted, "while the mentoring relationship is important in career development for both genders, it is particularly critical for women, especially those in male dominated professions such as the sport industry" (p. 3). Because sport has traditionally been a male-dominated area and women have been underrepresented in upper level managerial positions, several researchers have called for more work to examine mentoring for women in the field of sport management (Bower \& Hums, 2013; Shaw, 2006; Weaver \& Chelladurai, 2002). While mentoring is an imperative suggestion for the advancement of women, another important aspect of this study explores mentoring as it relates to opportunities for advancement known as career breakthroughs (Mainiero, 1994; Ohlott et al., 1994).

\section{Career Breakthroughs}

Career breakthroughs include events, people, or actions that help individuals overcome perceived career obstacles (Metz \& Tharenou, 2001). Considering women are more likely to experience challenges or barriers to advancement (Dunn-Jensen \& Stroh, 2007; Kumra \& Vinnicombe, 2010; Whitmarsh, Brown, Cooper, HawkinsRogers, \& Wentworth, 2007), women may benefit from career breakthroughs afforded through mentorship. Building on career breakthrough examples from previous research (Mainiero, 1994; Ohlott et al., 1994), this study identified career breakthroughs in intercollegiate athletics as: opportunities for new functional roles, opportunities for new projects, opportunities for supervision, committee assignments, and sport oversight.

Though career breakthroughs have received somewhat limited attention in the sport management literature, exploring career breakthroughs could be particularly important to the advancement of women in intercollegiate athletic administration. In male-dominated industries like intercollegiate athletics, women may have difficulty accessing mentors; thus, women may be deprived of opportunities for increased compensation, career advancement, and even career satisfaction (Weaver \& Chelladurai, 2002). Although mentoring relationships have been found to contribute to women's interest and tenure in intercollegiate athletics (Bower \& Hums, 2013) little research exists on exactly how mentoring, internal or external, may contribute to career breakthroughs.

As part of a larger study that examined women and leadership in intercollegiate athletics, this study examined the role of mentoring as it pertains to career breakthroughs for women in intercollegiate athletic administration. The following research questions guided this study:

- Why do women perceive mentors as important in their respective jobs and careers?

- How do women develop mentoring relationships?

- What factors contribute to a mentoring relationship?

\section{Method}

To serve the purpose of this study and to better understand the depth and breadth of mentoring, a qualitative approach was used (Creswell \& Plano Clark, 2011). Through the collection of qualitative data (i.e., focus groups), the results of this 
study provide a better understanding of mentoring in relation to career breakthroughs for women in intercollegiate athletic administration.

\section{Focus Groups}

Procedures. Qualitative data regarding the workplace experiences of athletic administrators were gathered from participants in six focus groups, which were conducted on site during a national athletic administrator's conference. Focus groups are particularly useful for this study because they bring "together people of similar backgrounds and experiences" (Patton, 2002, p. 236) to discuss issues in a subject or field. Groups were comprised of six to nine female participants with the title of assistant athletic director/commissioner, associate athletic director/commissioner, or athletic director/conference commissioner. The size of the focus groups were small enough to allow everyone the opportunity to speak, yet also large enough to provide diversity of opinions (Krueger \& Casey, 2009). Two focus group moderators were present in each focus group. Both moderators were taking notes throughout the discussion group to ensure accuracy of the data obtained and to assist with any questions or disagreements when it came to coding (Krueger \& Casey, 2009). Further, moderators used informal member checking by verbally summarizing participant's statements to also ensure and validate the accuracy of responses (Erlandson, Harris, Skipper, \& Allen, 1993).

The focus group moderators asked open-ended questions from a semistructured interview protocol. The interview protocol addressed participants' perceptions regarding career development and success. Questions on the protocol included, "What resources are needed to be a successful administrator?" "What support have you received that allowed you to be successful in your current position? Career?" and "How have mentors helped you in obtaining success as an athletic administrator?" Each focus group lasted approximately 60-75 min; they were recorded and transcribed verbatim resulting in six focus group transcripts.

Participants. Fifty-one $(n=51)$ participants represented NCAA Division I (54.8\%), NCAA Division II (19.6\%), and NCAA Division III (24.5\%) in the focus group. Participants held the titles of assistant athletic director/commissioner $(33.3 \%)$, associate athletic director $(43 \%)$, or athletic director/commissioner $(23.5 \%)$. Focus group participants identified as White $(90 \%)$, Black $(9.8 \%)$, or Asian American (1.9\%). The occupational tenure average was 12.5 years and the organizational tenure was 6.1 years.

Data Analysis. The four researchers divided in to teams of two. Each pair was responsible for independently coding three focus group transcripts in two coding cycles (Saldaña, 2013). The initial open-coding process resulted in the creation of codes and emerging themes. Following the open-coding process, research teams convened to debrief, compare codes or themes, and clarify findings and meanings of coded data for agreement. During the second cycle, research pairs engaged in axial coding, which provided the opportunity to connect codes from the open coding process. Second cycle axial coding helped create a clearer context in which internal and external mentoring contributed not only to career satisfaction, but also perceptions of career success. After second-cycle coding, the research pairs convened as the larger research team (four in total) to debrief, compare findings, 
and clarify meanings for agreement (Saldaña, 2013). All members of the research team discussed any disagreements, which were resolved through peer debriefing until the group came to consensus on the analysis. The team also used several strategies to establish trustworthiness of the data: including verbatim transcription (Patton, 2002), triangulation across researchers and participant experiences (Patton, 2002), and analytic memos and field notes (Miles, Huberman, \& Saldaña, 2014).

\section{Results}

Data from focus groups were organized into four primary findings: developing a mentoring relationship, benefits of mentoring, becoming a mentor, and cross-gender mentoring. Findings revealed why women perceived they needed a mentor, the benefits a mentor provides, the desire to serve as a mentor, and the diverse roles men and women have in mentoring relationships.

\section{Developing a Mentoring Relationship}

Across NCAA divisions and positions (i.e., assistant, associate, or athletic director) the focus group findings suggested having a mentor was highly desired. Women in this study obtained mentors through various avenues, but seemed to experience more successful mentoring relationships through informal networking or other relationship building opportunities:

Personally, I have not (had access to) certain types of resources or formal channels. I think for me it just happened a little more naturally and it's been with the relationships within the athletic department or on campus or just individuals that I have worked with in the past. (Associate Athletic Director)

A couple of my co-workers tried a mentor program. They were being proactive, they were trying to contact their mentors and just no response. It made me so grateful I had mentors that had just, kind of, developed. I didn't have to go through formal channels because I don't know how you get them to work. (Assistant Athletic Director)

Regardless of the way a mentoring relationship was developed, the women in our study also discussed the perceived benefits of having mentors internal and external to their respective athletics departments.

\section{Perceptions and Benefits of Mentors}

Women in the focus groups looked to mentors for support, encouragement, and insight on issues ranging from navigating organizational politics to decision making practices. One assistant athletic director described her Athletic Director as a mentor:

I have a great athletic director that has supported me. She is the one that said, "You can do this and whatever you need to do this," she constantly has reinforced my abilities and trying to have me gain the confidence in myself. (Assistant Athletic Director) 
Similarly, another Assistant Athletic Director appreciated how her "boss" whom she also considered a mentor could not only "show her the ropes," but also actively sought to "galvanize our group and we are slowly getting more females in our department." In other words, the mentor was not only helpful in working with this Assistant Athletic Director to navigate the athletic department (and perhaps the industry), but also engaged other women to create a network of support. In addition, internal mentors provide consistent engagement and organizational access:

It's literally a mentor relationship every single day and they make me a part of their senior team, so I am one of the top three people in that department. I can't imagine giving that up because that truly is what makes (me) happy that (I) get to learn from them every day. (Assistant Athletic Director)

Through this Assistant Athletic Director's mentoring relationship daily exposure to organizational decisions and decision makers may contribute to creating career breakthrough opportunities.

Other women found mentoring relationships helpful when tackling difficult issues at work. For example, an Associate Athletic Director described having a positive relationship with her Athletic Director, but preferred to work with a mentor on certain issues:

I have a mentor that I still rely on heavily when I'm faced with different issues. I do have a good relationship with my Athletic Director, too. I can go to him, but sometimes there's things that maybe I don't necessarily want to discuss with him and try to come up with a different view. That I have someone I can go to. (Associate Athletic Director)

In the above response, it is not clear if the mentor was in the same athletic department (internal) or an external colleague at another college or university. Undoubtedly, having a relationship with a mentor in the same athletic department is beneficial; however, having a mentor external to their respective athletic departments also had merit:

I need that [external] mentor. And I need someone outside of my conference that I can trust for safe conversation.... So, having somebody in the situation that has worked for me and is an AD [Athletic Director] someplace else. We are safe phone call sharing kinds of things, so that has just been huge, huge difference. A mentor is outside of my own institution. (Assistant Athletic Director)

In addition, another Athletic Director and Assistant Athletic Director noted the role of external mentorships throughout their careers:

My mentors were distant. They were the Christine Grants. They were all of the people up there at the front of the AIAW conventions. The dean of the school of education, was a mentor. Not in athletics, but yet in that capacity. (Athletic Director)

That was helpful in my journey and I think having that external resource outside of general athletics was very helpful to have those people and to watch through that. I know that not everybody has that ability, but just being part of 
a different organization and my state support was what helped me find those mentors. (Assistant Athletic Director)

External mentorship was important for women who needed a different perspective or were seeking a "safe zone" of conversation with someone outside of their athletic department or, even, outside of intercollegiate athletics. However, despite the benefits of external mentorship, there were drawbacks for the mentor and protégé noted by participants as explained by an Associate Athletic Director:

I know that when I have been paired up with women, some wonderful people, but they are always very far away, and so you are creating a relationship (... alluding to distance) but it's very difficult. I have been paired with many women, one of them is in Connecticut and North Carolina, and they are lovely people, it's just that we are never in the same place in the same time.

In addition to the challenge of physical distance a few women expressed the difficulty of maintaining external mentoring relationship, but also recognized the importance of such mentors. One Athletic Director described a network or constellation of external mentoring relationships as a "toolbox:"

I think the toolbox of mentor idea is really valuable to me in different phases or conditions... It has been very helpful to meet other folks or people who have been just in a position much longer than I have been. They're very helpful people to just pick up the phone and call people... I think that has probably made it easier to be able to help this along the way. (Athletic Director)

In other words, calling on different managerial perspectives, experiences, and lenses may equip the protégé with different "tools" for handling challenging situations.

Mentorship, internal or external, provided women in this study opportunity for personal and professional growth. Since the opportunities afforded through the mentor-protégé relationship were mainly beneficial, many women-particularly those in the late stages of their careers-expressed the desire to become a mentor.

\section{Becoming a Mentor}

Women currently serving as Athletic Directors expressed a desire for mentoring protégés because it was perceived as an "important" thing to do for people interested and currently working in intercollegiate athletic administration. In fact, the women who addressed this were quite passionate, indicating they felt a responsibility to give back to other women in the profession. Two Athletic Directors stressed the importance of mentoring others:

This year, for the first time, I have a couple different mentoring situations. Actually, I had a junior in high school email me and she was able to do an internship and she was maybe interested in sports administration. I'm one of those, when it comes to mentoring, I never say no. She comes three times a week and we talk about a whole lot, got her around to the different departments, so she could see what was there. I've got a male doctoral student who's doing his doctorate at (State University), but he works at (a different university) and he 
asked me to be his mentor, because he wants to get into more of the athletics academic advising and things of that nature. I'm also doing that. If anybody asks, I'm going to do whatever I can. One person I mentored is now an AD [Athletic Director] and another one I know is going to be an AD pretty soon. For me, it's just, I'm going to give back whatever I can. It's vitally important.

I just think mentoring is the most important thing that we do. I would say, on average, three times a week I am meeting with someone, whether they're a law student who is interested in this type of career or whether an MBA student. ... We've also created a list of people with ties to our institutions because most of the people I mentor are people affiliated with our institution. It's part of the educational process, I think. I've created contact sheets for everybody who's ever been at our institution that is now somewhere else in collegiate athletics. It's a who's who.... It's associate AD's and AD's and conference commissioners and just encouraging people that don't be shy about reaching out because I might not be the best mentor for you, but here are other people with the title or institution that could be the perfect match for you. I just think it's so important.

The Athletic Directors viewed mentoring as a vital component of their job. This was interesting, as mentoring is not a formal job requirement, yet the Athletic Directors felt compelled to help other women. The importance of mentoring, as illustrated by the comments shared by Athletic Directors, also reflects the diversity of mentoring relationships from students and professionals to men and women. As such, the nature of cross-gender mentoring relationships arose with several of our participants.

\section{Cross-gender mentoring.}

Several women in this study often identified mentors by their areas of expertise, but gender often, knowingly or unknowingly, played a role in how the mentorship developed. One Assistant Athletic Director described having a male and female mentor:

The Assistant AD (male) and our SWA (female) mentor me and it's kind of interesting because with (the SWA), she is always like, "Here is the political way of getting it done" and with him you can see it's, "Here just barge in here and do it," and it's very different approaches. Here is the political way versus "why wouldn't you just go do it?" It's very interesting because their approaches are different, but they are also looking ... I feel like their experiences have been different too and there's different things that the person may need versus what I need, but at the same time sometimes there is that part of me that wonders, "why am I not being told to just charge in there and do it?"

The juxtaposition observed by this Assistant Athletic Director between how a female mentor and a male mentor suggest approaching various situations also brings to bear how gender roles are reinforced or challenged by male and female mentors. Another Athletic Director described having male mentors that were to her detriment, "I've had some very poor male mentors that were in positions aspired to and consequently got passed over for those." While another participant (an 
Assistant Athletic Director) suggested that having a male mentor helped her feel "more confident" in seeking out other male mentors. For others, finding a mentor of a particular gender was of little importance:

I work in media ... I never really looked for a female mentor because I just didn't really yet grasp the difference between working with a man and working with a woman. (Associate Athletic Director)

Although gender was noted by participants and they were aware of varying gender dynamics related to the mentoring relationship, there did not appear to be a clear preference, or partialness to having one gender over the other; but rather a recognition of the differences for men and women. Although it appears gender played a role in the mentoring relationship, the fact that participants were being mentored superseded whether the mentor was male or female. Ultimately, it seems participants recognized some differences in the situations their mentors faced and how gender might have contributed. Participants could also see the reality of how gender was an influencing factor in the operations of and leadership within intercollegiate athletic departments. These experiences for women could provide valuable understanding of the impact of gender at work.

Regardless of gender of the mentor or whether that mentor is internal or external to an athletic department, it is the apparent mentoring relationships that are important to women for various personal and professional reasons. Mentors provide support and encouragement, varied perspectives on issues affecting intercollegiate athletics or career paths, access to resources, and a knowledge base beneficial to protégés. Mentoring has the potential to not only assist women with career breakthroughs, but may also provide the support necessary for women to feel satisfied in their jobs and careers.

\section{Discussion}

Access to leadership positions within intercollegiate athletics continues to be challenging for women, as fewer than $23 \%$ hold the most senior leadership position of athletic director across all NCAA divisions (Acosta \& Carpenter, 2014). One area of professional development, widely supported both in research and in practice, that assists individuals in career advancement is mentorship (Allen et al., 2004; Bower \& Hums, 2013; Ramaswami et al., 2010; Singh et al., 2009a). To better understand how mentorship impacts career development for women in intercollegiate athletic administration, this study examined the role of mentoring as it pertains to career breakthroughs.

Based on findings, our focus group participants indicated that mentorship is critical to their professional development (Ibarra et al., 2010). Professional development included access to networks, new job responsibilities, and opportunities to develop new skill sets. While it is important women have the opportunity to seek new job responsibilities to advance, it is also important for women to be proactive in identifying and seeking a mentor that can provide opportunities for growth in responsibilities and managerial oversight (Blickle, Witzki, \& Schneider, 2009). For women in this study, the perceived importance of sport oversight, particularly in a revenue-generating sport, signified a responsibility identified as an important 
career breakthrough. Therefore, it is important for women to seek and engage with mentors who currently have or have had sport oversight. Protégés that are proactive in seeking mentors, particularly early in their careers, may have more opportunity for career success (Blickle et al.).

Interestingly, Metz and Tharenou (2001) reported career breakthroughs as more beneficial to women at high managerial levels, rather than women in lower levels of administration. The findings of this study refute Metz and Tharenou in that career breakthroughs were found to be of importance to women in early and midcareer stages of intercollegiate athletic administration. This is important as women in our study who were early in their careers (less than 10 years) deemed it important to seek opportunities for breakthroughs. Moreover, the emphasis on career breakthroughs provides evidence that women may now perceive opportunities to advance to higher levels of athletic administration. This is a particularly important finding given that previous research on women in intercollegiate athletics suggests that women may perceive the opportunity for promotion and advancement to be limited in part to male-dominated organizational structures and the negative gender stereotypes women face in gendered organizations (Burton et al., 2011; Hancock \& Hums, 2016; Shaw \& Frisby, 2006). As young female administrators perceive opportunities for advancement, this might also echo a perceived shift in the gendered culture and power structure of their respective athletic departments (Hancock \& Hums, 2016). Perhaps the perception of a shift is also the product of the mentoring relationships.

Further, the benefits participants sought as critical to the mentoring relationship included psychological aspects such as support, encouragement, and insight. As consistent with earlier studies on mentorship the sport industry, encouragement and support, advice, opportunity to increase knowledge, guidance and direction, and constructive criticism have been noted as important benefits participants received from mentoring (Bower \& Hums, 2013; Young, 1990). Identifying the perceived benefits one seeks in a mentor is an important step in the process of developing a mentoring relationship. Engaging in mentoring relationships with individuals who have the attributes perceived to contribute to career development and advancement is an imperative career strategy that the participants in our study clearly recognize.

Participants also indicated a desire for internal mentorship at both a peer level (e.g., coworker or someone with a comparable position) and with someone more senior in their organization. Kram $(1983,1985)$ noted clear benefits to internal peer mentoring, which study participants also discussed. Internal peer mentoring may be more readily accessible and available for women allowing for ease of communication, collaboration, and feedback. These are important components of an internal mentor (Eshner et al., 2001) and particularly important for women protégés if they want to advance at their current institution. Further, peer mentoring can allow for a different dynamic in the mentoring process as there may be a more mutual reciprocity in the relationship. However, our participants also indicated they sought someone more senior in the organization for a mentor. Thus, participants recognize the positive career and psychological assistance, including advocacy, exposure, visibility, and counseling that a more senior member in the field could provide. As Eshner and colleagues (2001) suggested protégés need to develop a network of mentoring. The fact that our participants indicated a desire for both an internal peer mentor as well as a senior mentor could potentially provide them an advantage. 
Having an external mentor, someone outside of the athletic department, was also critical to career advancement. Respondents indicated that external mentors used their influence to support the protégés advancement in the field of intercollegiate athletic administration. These findings exemplify the extended professional networks external mentors can offer protégés (Baugh \& Fagenson-Eland, 2005). Though focus group participants discussed the advantages (e.g., sounding board, objective perspective) of having an external mentor, the physical distance between the protégé and external mentor inhibited frequency of communication. Still, external mentors also seemed to offer a "safe zone" for protégés. While participants did not explicitly state why "safe zones" were important beyond talking to a trusted colleague as a sounding board, this could be evidence that women feel vulnerable discussing job or career challenges. Further, because women in this study were in management positions in college athletics, they are also highly visible. In a maledominated profession, visibility is a double-edged sword as it has the potential to result in criticism or praise (Corby \& Stanworth, 2009; Kanter, 1977; Whitmarsh et al., 2007). As a result, women in senior management positions may feel pressure to "prove" their abilities to colleagues (Grappendorf \& Lough, 2006; Whitmarsh et al., 2007). A trusted, external mentor may provide the space needed for a protégé to share vulnerabilities without resulting in criticism or perceived weakness from colleagues.

An additional finding that surfaced in the focus group data were the recognition by women in more senior level positions of the important role they provide as mentors to women in lower administrative positions. This is consistent with and supports the notion that women in intercollegiate athletic administration sought opportunities to provide mentoring to other women looking to advance their careers (Bower \& Hums, 2013). The willingness of senior-level administrators to support junior-level female administrators in athletic departments could make positive contributions toward increasing the number of women in senior leadership. Previous research found that women in top management positions have a positive effect on increasing representation of women in lower-level managerial ranks (Kurtulus \& Tomaskovic-Devey, 2012). In addition, since men in senior leadership positions are more likely to assign challenging tasks to male subordinates than to female subordinates (Mai-Dalton \& Sullivan, 1981; Martin, 2003), and challenging work experiences are more available for men (Van Velsor \& Hughes, 1990; Hoobler, Lemmon, \& Wayne, 2014), increasing the representation of women mentors in senior managerial ranks could also increase the number of career breakthrough opportunities for women. This is particularly important as recent research has shown that women administrators in intercollegiate athletics feel their professional networks have inhibited career growth as networks are often dominated by men (Huberty, Moore, Binegar, \& Marks, 2016).

While there is not a direct connection to mentoring, increased proportions of women in higher-levels of management offer more opportunities for women to be mentored by women (Greenhill, Auld, Cuskelly, \& Hooper, 2009; Whisenant, Pedersen, \& Obenour, 2002). Furthermore, as more women in higher administrative positions seek opportunities to mentor other women, the burden of perceived expectations and responsibilities of mentoring younger females once experienced by high-ranking administrative women might be lessened (Cullen \& Luna, 1993; Ritchie et al., 1997). Finally, as more women seek opportunities to mentor women 
protégés, there is a likelihood women can create a mentoring pipeline. That is, when a woman has a mentor, she is more likely to become a mentor (Young, 1990; Faucette \& Nugent, 2012).

Cross-gender mentoring was also addressed by participants. Cross-gender mentoring is defined as a man mentoring a woman or a woman mentoring a man. Participants often noted the gender of their mentors, as well as some of the dynamics that they experienced with both male and female mentors. It became evident that cross-gender mentoring in intercollegiate athletic administration is an area that should be further examined. For example, Ramaswami et al. (2010) found women and men in male-dominated occupations were more likely to benefit from having male mentors. More specifically, women in male-dominated organizations who also reported having male mentors reported higher levels of career satisfaction. Dougherty, Dreher, Arunachalam, and Wilbanks (2013) also explored cross-gender mentoring in male- and non-male-dominated occupational contexts. Women in male-dominated occupations who had a male mentor earned a considerably higher salary than women with a male mentor in a non-male-dominated occupation. In fact, women with male mentors in male- and non-male-dominated occupations were more likely to earn a higher salary than men in the same occupational contexts. While salary has been attributed to career satisfaction and was also identified as an outcome of a cross-gendered mentoring relationship, such a variable offers little insight as to how gender dynamics impact mentoring relationships.

Conversely, some benefits may occur from having a same-gender (femalefemale) protégé/mentor relationship as women are likely to understand the unique challenges facing other women in the workplace. Participants in the study indicated they were aware of the differing gender dynamics and observed how their mentors dealt with or advised them on issues; they appeared to appreciate the insight into those dynamics they witnessed by working their mentors. By working with both male and female mentors, participants gained valuable insight into the reality of the role gender plays in the leadership ranks of intercollegiate athletics. Still, despite the benefits, females are less like to have a female mentor, "probably due to too few women are in sufficiently advanced positions to provide mentoring to junior colleagues" (Dworkin et al., 2012, p. 366). Interestingly, women's mentors-regardless of gender -often have less organizational clout and are therefore less likely to help women advance in their careers (Ibarra et al., 2010). Still, the desire to have male and female mentors also underscores the importance of constellation mentoring. Thus, the field of sport management should further investigate the composition and dynamics of such relationships.

\section{Implications}

The theoretical and practical implications of the results of our study are important for women athletic administrators seeking opportunities for career advancement, breakthroughs, and strategies for being more satisfied in their careers. Women face complex challenges working in intercollegiate athletic administration, so gaining further understanding about opportunities is important as women navigate their careers. Theoretically, the current study answers researchers' (Bower \& Hums, 2013; Shaw, 2006; Weaver \& Chelladurai, 2002) call to examine mentoring for women in the male-dominated field of sport management, specifically intercollegiate 
athletics. In addition, this study illustrates the importance of mentoring on career breakthroughs and advancement.

A key principle of mentoring is that mentors help protégés advance their careers with career and psychological support (Kram, 1985). Thus, it was no surprise that in this study, protégés also sought mentors for those same reasons. Mentor support aided protégés in seeking and gaining opportunities for career advancement. As noted in a previous study (Singh, Ragins, \& Tharenou, 2009b), mentoring may support a protégé's advancement expectations and opportunities (e.g., career breakthroughs), while simultaneously assisting the protégé with envisioning success in their respective organizations. Furthermore, Singh et al. (2009b) suggested that envisioning success within an organization might reduce turnover intentions. If we apply this perspective to women administrators in college athletics, mentoring may contribute not only to more women pursuing careers in intercollegiate athletic administration, but also longer career tenures with continued opportunities for advancement. By earning more opportunities for breakthroughs and gaining experience in crucially-deemed areas like supervision of revenue generating sports, women in intercollegiate athletic administration may feel as though they have more potential to advance and thus stay in the field. Further, as previously mentioned, increasing the proportion of women in athletic administration, specifically in senior levels, also increases the likelihood that women can mentor other women.

From a practical standpoint, several avenues should be considered by all leaders working in sport organizations, with focus on women working in athletic administration. As noted by Singh et al. (2009b), "Members of non-dominant groups may be less likely to be on the 'fast track' because of the glass ceiling and walls and are often excluded from the 'good ol boys' networks that are the training grounds for honing strategies for career success" (p. 15). Thus, women interested in career growth should proactively seek and form both internal and external mentoring relationships, whether formal or informal, with male and female mentors to facilitate their career advancement. For women, a broad constellation of mentors may offer them more opportunities for career development, exposure, and sponsorship.

Professional organizations including Women Leaders in College Sports (WLCS; formerly the National Association for Collegiate Women Athletic Administrators, NACWAA) and the National Association of Collegiate Directors of Athletics (NACDA) now offer informal and formal mentoring programs and institutes. Informal mentoring relationships "develop on the basis of mutual identification and the fulfillment of career needs" (Ragins \& Cotton, 1999, p. 530). Often informal mentoring occurs at the early stages of a protégé's career and involves a mentor who identifies as a midlevel manager. Mentors in informal relationships select protégés they perceive to be younger versions of themselves to pass down knowledge and wisdom to future generations. Conversely, the protégé selects a mentor they view as a role model and someone who can provide guidance to help achieve long-term career goals (Ragins \& Cotton). For both the mentor and protégé, the mentorship is founded on perceived competence and the strength of an interpersonal relationship. In other words, mentors seek protégés they perceive to be capable of successful career growth, while protégés seek mentors who possess a desired skill set. Given the close interpersonal nature of informal mentorships, the relationship may last several years. As such, informal mentoring is likely to fulfill psychosocial functions as well as career functions (Ragins \& Cotton). 
A formal mentor/protégé relationship is one in which the mentor and protégé are "assigned to one another by a program coordinator based on application forms submitted by the potential mentor and protégé" (Ragins \& Cotton, 1999, p. 530). Mentors and protégés are paired on the perceived competency of the mentor, not on mutual interest or career goals. Often, however, the mentor and protégé never meet or converse until after the match is made. Therefore, previous role modeling and interpersonal relationship cultivation is absent; psychosocial functions may occur less (Ragins \& Cotton) or in later stages formal mentoring relationships as the mentor/protégé develop rapport. However, formal mentorships generally last 6-12 months (Ragins \& Cotton); thus, these mentoring relationships tend to focus on career functions like skill development and access to networks, rather than developing self-confidence or friendships with the protégé.

To enhance these programs, organizations like WLCS and NACDA would do well to educate their members on the types and purposes of mentoring relationships. When mentors and protégés understand the various advantages and challenges to different mentorships, the mentor and protégé can work together to build a partnership that is mutually beneficial. Further, due to the nature of mentoring, time, dedication, and resources are necessary of both parties; expectations for the mentor program should be discussed and agreed before the start of the program.

Conversely, individual athletic departments might not have the luxury (e.g., budget, time, personnel) of developing formal mentoring programs; however, athletic departments could provide financial incentives (e.g., travel, membership costs, program fees) for identified talent to attend WLCS, NACDA, or other professional development programs to gain access to other mentors. While mentoring relationships may connect the protégé to a vast network outside of the athletic department, it is important for supervisors to remember that mentoring improves job satisfaction and may increase organizational commitment and reduce turnover (Baranik et al., 2010; Bozionelos et al., 2011). Therefore, investing in mentoring opportunities for talented employees, especially those early in their careers, may help athletic department retain strong employees.

Cross- and same-gender mentoring relationships offer unique developmental opportunities with varying benefits (Dougherty et al., 2013; Janssen, van Muuren, \& de Jong, 2014; Ramaswami et al., 2010). Thus, broadening one's perspective on whom can serve as a mentor to include both male and female mentors may be of value. Women in intercollegiate athletic administration as well as men and women in senior administrative positions need to recognize the benefits of both cross and same-gender mentorships. In addition, organizations should also be proactive in supporting mentoring relationships that involve the development of all employees, not just those with potential or considered rising stars (Singh et al., 2009b).

Based on our findings, every stage of our participants' careers were impacted by mentorship. Whether an individual was seeking a mentor, working with a mentor, or serving as a mentor, opportunities were afforded to each of them. It is also imperative organizations, including professional societies, provide platforms to encourage, establish, and cultivate mentoring relationships. This could include providing mentorship training to and for mentors and protégés in leadership courses or leadership development programs. In addition to mentoring, collegiate athletic departments, sport organizations, and more generally male-dominated industries, need to create and encourage more career breakthrough opportunities for women 
because even though male and female candidates may have similar career paths and job titles, women have not had the same responsibilities as men (Burton et al., 2011; Ohlott et al., 1994; Yiamouyiannis \& Osborne, 2012). As such, career breakthroughs provide women an opportunity to be exposed to challenging experiences, so they are not eliminated from a candidate pool due to a lack of exposure or perceived lack of exposure and qualification.

\section{Limitations and Future Directions}

As with all research, limitations of a study must be acknowledged. Since most our focus group participants were representatives from NCAA Division I institutions, future research could focus on recruiting more participants from other NCAA Divisions and those outside of the NCAA (e.g., NAIA, NJCAA). As such, a vast representation may reveal other unique benefits and challenges of mentorship. In addition, most participants in the study were White. Future studies should consider the experiences of women of color, specifically, the intersections of race and gender in intercollegiate administration. Limited research suggests that race and racial identity may negatively impact a candidate seeking a high-level administrative position in college athletics (Steward \& Cunningham, 2015). In addition, Black female athletic administrators must often navigate additional social, personal, and organizational challenges (McDowell \& Cunningham, 2009) because of their gender and race. McDowell (2009) suggested that Black women must also contend with "ideological beliefs about how they obtain their leadership positions" (p. 19). For example, Black women, particularly those in senior administration, may be perceived as "quota hires" rather than being hired based on qualifications and talent. Further, we recognize the experiences of women of color in administration at historically Black colleges and universities (HBCU) may differ from the experiences of Black women at predominately White institutions (PWI). Therefore, insight into the experiences of women of color at HBCUs and PWIs might offer a better understanding of the deeply embedded social constructions of gender and race in intercollegiate athletic administration. Research of this kind would bring attention to where, how, and why inequities occur in an organizational hierarchy (Ely, 1995) and how those inequities might contribute to or inhibit career advancement opportunities for women and women of color. Efforts to recruit and gain the insight of women are color should be made in future studies.

Due to limited research, particularly in the field of sport management, advantages of external mentoring should be further explored. Second, investigating ways to overcome geographic and technological barriers to mentoring relationships could be helpful to advancing the mentoring literature. Third, our study suggests a relationship between mentoring and career breakthroughs. New research may seek to measure the relationship between mentoring and career breakthroughs as findings could provide further insight into the benefits of mentoring relationships. Fourth, mentoring may contribute to career satisfaction, which may in turn increase organizational commitment and reduce turnover (Baranik et al., 2010; Bozionelos et al., 2011). While this is supported with previous research (Blickle et al., 2009), it is also in contrast to Singh et al. (2009b), which found no relationship between mentoring and career satisfaction. Given this difference, additional research is needed to explore the relationship and possible predictive nature of mentoring on career satisfaction and career breakthroughs. 
Finally, the idea of taking mentoring relationships to the next level by participating in actual sponsorship (Hewlett, Peraino, Sherbin, \& Sumberg, 2011) for women in sport management could be impactful to the industry. A sponsor is in a decision-making position and uses his or her platform to publicly advocate and protect the advancement of an individual (Hewlett et al., 2011). Since $80.3 \%$ of the women in this study had external mentors who used their influence to support the respondent's advancement in the field, having a sponsor be more detailed and precise regarding planning protégé career moves, publicly endorsing and supporting them as well as encouraging and allowing them take charge in new roles will enhance the protégé's recognition and credibility in the field. Fifth, we would encourage a closer examination of different methods and types of mentoring that could be beneficial for women in sport management. There are many options from traditional to peer mentoring, formal to informal, or group to individual. As women continue to work and advance in the management and administrative ranks in intercollegiate athletics and other areas of the sport industry, we must continue to engage in applicable research regarding mentoring that can best benefit them.

\section{References}

Acosta, R.V., \& Carpenter, L.J. (2014). Women in intercollegiate sport: A longitudinal, national study thirty-seven year update. Retrieved http://www.acostacarpenter.org/

Aicher, T.J., \& Sagas, M. (2009). An examination of homologous reproduction and the effects of sexism. Journal for the Study of Sports and Athletes in Education, 3(3), 375-386. https://doi.org/10.1179/ssa.2009.3.3.375

Allen, T.D., Eby, L.T., Poteet, M.L., Lentz, E., \& Lima, L. (2004). Career benefits associated with mentoring for protégés: A meta-analysis. The Journal of Applied Psychology, 89(1), 127-136. PubMed https://doi.org/10.1037/0021-9010.89.1.127

Anderson, E.D. (2009). The maintenance of masculinity among stakeholders of sport. Sport Management Review, 12(1), 3-14. https://doi.org/10.1016/j.smr.2008.09.003

Baranik, L., Roling, E.A., \& Eby, L.T. (2010). Why does mentoring work? The role of perceived organizational support. Journal of Vocational Behavior, 76(3), 366-373. PubMed https://doi.org/10.1016/j.jvb.2009.07.004

Baugh, S.G., \& Fagenson-Eland, E.A. (2005). Boundaryless mentoring: An exploratory study of the functions provided by internal versus external organizational mentors. Journal of Applied Social Psychology, 35(5), 939-955. https://doi.org/10.1111/j.1559-1816.2005. tb02154.x

Baumgartner, M.S., \& Schneider, D.E. (2010). Perceptions of women in management: A thematic analysis of razing the glass ceiling. Journal of Career Development, 37(2), 559-576. https://doi.org/10.1177/0894845309352242

Blickle, G., Witzki, A., \& Schneider, P.B. (2009). Self-initiated mentoring and career success: A predictive field study. Journal of Vocational Behavior, 74(1), 94-101. https:// doi.org/10.1016/j.jvb.2008.10.008

Boddy, J., Agllias, K., \& Gray, M. (2012). Mentoring in social work: Key findings from a women's community-based mentoring program. Journal of Social Work Practice, 26(3), 385-505. https://doi.org/10.1080/02650533.2012.670103

Bower, G.G. (2009). Group mentoring as an alternative model for women. Women in Sport and Physical Activity Journal, 18(2), 80-84. https://doi.org/10.1123/wspaj.18.2.80

Bower, G.G., \& Hums, M.A. (2013). Career paths of women working in leadership positions within intercollegiate athletic administration. Advancing Women in Leadership, $33,1-14$. 
Bozionelos, N., Bozionelos, G., Kostopoulos, K., \& Polychroniou, P. (2011). How providing mentoring relates to career success and organizational commitment. Career Development International, 16(5), 446-468. https://doi.org/10.1108/13620431111167760

Britton, D.M., \& Logan, L. (2008). Gendered organizations: Progress and prospects. Sociology Compass, 2(1), 107-121. https://doi.org/10.1111/j.1751-9020.2007.00071.x

Bryant, S. (2015, February 13). The best Fortune 500 mentorship programs. Retrieved http:// www.investopedia.com/articles/personal-finance/022315/best-fortune-500-mentorshipprograms.asp

Burke, R.J., \& McKeen, C.A. (1996). Gender effects in mentoring relationships. Journal of Social Behavior and Personality, 11(5), 91-104.

Burton, L.J., Barr, C.A., Fink, J.S., \& Bruening, J.E. (2009). "Think athletic director, think masculine?": Examination of gender typing of managerial subroles within athletic administration position. Sex Roles, 61(5-6), 416-426. https://doi.org/10.1007/s11199009-9632-6

Burton, L.J., Grappendorf, H., \& Henderson, A. (2011). Perceptions of gender in athletic administration: Utilizing role congruity theory to examine (potential) prejudice against women. Journal of Sport Management, 25(1), 36-45. https://doi.org/10.1123/ jsm.25.1.36

Chao, G.T. (1998). Invited reaction: Challenging research in mentoring. Human Resource Development Quarterly, 9(4), 333-338. https://doi.org/10.1002/hrdq.3920090404

Connell, R. (2009). Gender. Cambridge: UK Polity.

Corby, S., \& Stanworth, C. (2009). A price worth paying? Women and work - Choice, constraint, or satisficing. Equal Opportunities International, 28(2), 162-178. https:// doi.org/10.1108/02610150910937907

Creswell, J.W., \& Plano Clark, W.L. (2011). Designing and conducting mixed methods research (2nd ed.). Thousand Oaks, CA: Sage.

Cullen, D.L., \& Luna, G. (1993). Women mentoring in academe: Addressing the gender gap in higher education. Gender and Education, 5(2), 125-137. https://doi. org/10.1080/0954025930050201

Cunningham, G.B. (2008). Creating and sustaining gender diversity in sport organizations. Sex Roles, 58(1-2), 136-145. https://doi.org/10.1007/s11199-007-9312-3

Dougherty, T.W., Dreher, G.F., Arunachalam, V., \& Wilbanks, J.E. (2013). Mentor status, occupational context, and protégé career outcomes: Differential returns for males and females. Journal of Vocational Behavior, 83(3), 514-527. https://doi.org/10.1016/j. jvb.2013.08.001

Dunn-Jensen, L.M., \& Stroh, L.K. (2007). Myths in the media: How the news media portray women in the workforce. In D. Bilimoria \& S.K. Piderit (Eds.), Handbook on women in business and management (pp. 13-33). Northampton, MA: Edward Elgar Publishing. https://doi.org/10.4337/9781847204134.00008

Dworkin, T.M., Maurer, V., \& Schipani, C.A. (2012). Career mentoring for women: New horizons/expanded methods. Business Horizons, 55(4), 363-372. https://doi.org/10.1016/j. bushor.2012.03.001

Eagly, A.H., \& Carli, L.L. (2003). The female leadership advantage: An evaluation of the evidence. The Leadership Quarterly, 14(6), 807-834. https://doi.org/10.1016/j. leaqua.2003.09.004

Erlandson, D.A., Harris, E.L., Skipper, B.L., \& Allen, S.D. (1993). Doing naturalistic inquiry: A guide to methods. Newbury Park, CA: Sage Publications, Inc.

Ely, R. J. (1995). The power in demography: Women's social constructions of gender identity at work. Academy of Management Journal, 38(3), 589-634.

Eshner, E.A., Thomas, C., \& Murphy, S.E. (2001). Comparison of traditional, stepahead, and peer mentoring on protégés support, satisfaction, and perceptions of career success. Journal of Business and Psychology, 15(3), 419-438. https://doi. org/10.1023/A:1007870600459 
Fagenson, E.A. (1989). The mentor advantage: Perceived career/job experiences of protégés versus non-proteges. Journal of Organizational Behavior, 10(4), 309-320. https://doi. org/10.1002/job.4030100403

Faucette, N., \& Nugent, P. (2012). Preservice teachers' responses to a peer mentoring innovation: The "Leavers" and "Completers.". Education, 132(3), 548-559.

Grappendorf, H., \& Lough, N. (2006). An endangered species: Characteristics and perspectives from female NCAA division I athletics directors of both separate and merged athletic departments. The Sport Management and Related Topics Journal, 2(2), 6-20.

Greenhill, J., Auld, C., Cuskelly, G., \& Hooper, S. (2009). The impact of organizational factors on career pathways for female coaches. Sport Management Review, 12(4), 229-240. https://doi.org/10.1016/j.smr.2009.03.002

Hancock, M.G., \& Hums, M.A. (2015). Career goals and expectations of female senior level administrators in NCAA Division I athletic departments. Global Sport Management Journal, 3(1), 21-42.

Hancock, M.G., \& Hums, M.A. (2016). “A leaky pipeline?” Perceptions of barriers and supports of female senior-level administrators in NCAA Division I athletic departments. Sport Management Review, 19, 198-210. https://doi.org/10.1016/j.smr.2015.04.004

Hewlett, S. A, Marshall, M., \& Sherbin, L. (2011). The relationship you need to get right: How to be an effective sponsor - and a good protégé- throughout your career. Harvard Business Review, 89, 131-134.

Hewlett, S. A., Peraino, K., Sherbin, L., \& Sumberg, K. (2010). The sponsor effect: Breaking through the last glass ceiling. Harvard Business Review Research Report.

Higgins, M.C., \& Kram, K.E. (2001). Reconceptualizing mentoring at work: A developmental network perspective. Academy of Management Review, 26(2), 264-288.

Higgins, M.C., \& Thomas, D.A. (2001). Constellations and careers: Toward understanding the effects of multiple developmental relationships. Journal of Organizational Behavior, 22(3), 223-247. https://doi.org/10.1002/job.66

Hoffman, J.L. (2011). Inside the huddle: Gender stereotyping work among senior-level women athletic administrators. International Journal of Sport Management, 12, 255-274.

Hoobler, J.M., Lemmon, G., \& Wayne, S.J. (2014). Women's managerial aspirations: An Organizational development perspective. Journal of Management, 40(3), 703-730. https:// doi.org/10.1177/0149206311426911

Huberty, L.L., Moore, M.E., Binegar, S., \& Marks, W. (2016). The bent of human resources theory on gender equality: Examining work conditions for female leaders in U.S. collegiate athletic organizations. Problems and Perspectives in Management, 14(3), 594-600. https://doi.org/10.21511/ppm.14(3-3).2016.01

Ibarra, H., Carter, N.C., \& Silva, C. (2010). Why men still get more promotions than women? Harvard Business Review, XXX, 80-85. PubMed

Janssen, S., van Muuren, M., \& de Jong, M.D.T. (2014). Motives to mentor: Self-focused, protégé-focused, relationship-focused, organization-focused, and unfocused motives. Journal of Vocational Behavior, 85(3), 266-275. https://doi.org/10.1016/j.jvb.2014.08.002

Kanter, R.M. (1977). Men and Women of the Corporation. New York: Basic Books.

Kelly, D.D., \& Dixon, M.A. (2014). Successfully navigating life transitions among African American male student-athletes: A review and examination of constellation mentoring as a promising strategy. Journal of Sport Management, 28(5), 498-514. https://doi. org/10.1123/jsm.2012-0320

Kihl, L.A., Shaw, S., \& Schull, V. (2013). Fear, anxiety, and loss of control: Analyzing an athletic department merger as a gendered political process. Journal of Sport Management, 27(2), 146-157. https://doi.org/10.1123/jsm.27.2.146

Knoppers, A. (1992). Explaining male dominance and sex segregation in coaching: Three approaches. Quest, 44(2), 210-227. https://doi.org/10.1080/00336297.1992.10484051

Kram, K.E. (1983). Phases of the mentoring relationship. Academy of Management Journal, 26(4), 608-625. https://doi.org/10.2307/255910 
Kram, K.E. (1985). Mentoring at work: Developmental relationships in organizational life. Glenview, IL: Scott Foresman.

Krueger, R.A., \& Casey, M.A. (2009). Focus groups: A practical guide for applied research. Los Angeles: Sage.

Kumra, S., \& Vinnicombe, S. (2010). Impressing for success: A gendered analysis of a key social capital accumulation strategy. Gender, Work and Organization, 17(5), 521-546. https://doi.org/10.1111/j.1468-0432.2010.00521.x

Kurtulus, F. A., \& Tomaskovic-Devey, D. (2012). Do female top managers help women to advance? A panel study using EEO-1 records. The Annals of the American Academy, 173-197.

Lapchick, R. (2016a). The 2016 racial and gender report card: National basketball association. Retrieved from http://nebula.wsimg.com/b9943b418cddb15b914 afb9d18b62e16?Access KeyId=DAC3A56D8FB782449D2A\&disposition=0\& alloworigin $=1$

Lapchick, R. (2016b). The 2016 racial and gender report card: National football league. Retrieved from http://nebula.wsimg.com/1abf21ec51fd8dafbecfc2e0319a6091?Acc essKeyId=DAC3A56D8FB782449D2A\&disposition=0\&alloworigin=1

Lapchick, R. (2016c). The 2016 racial and gender report card: Major league baseball. Retrieved from http://nebula.wsimg.com/811d6cc2d0b42f3ff087ac2cb690ebeb?Ac cessKeyId=DAC3A56D8FB782449D2A\&disposition=0\&alloworigin=1

Lapchick, R. (2017, April 6). The college sports racial and gender report car shows a reversal of progress. Retrieved from http://www.espn.com/mens-college basketball/ story/_id/19090953/troubling-trends-college-sport-racial-gender-report-card

LaPierre, T.A., \& Zimmerman, M.K. (2012). Career advancement and gender equity in healthcare management. Gender in Management, 27(2), 100-118. https://doi. org/10.1108/17542411211214158

Mai-Dalton, R.R., \& Sullivan, J.J. (1981). The effects of manager's sex on the assignment to a challenging or dull task and reasons for the choice. Academy of Management Journal, 24(3), 603-612. https://doi.org/10.2307/255578

Mainiero, L.A. (1994). Getting anointed for advancement: The case of executive women. The Academy of Management Executive, 8(2), 53-67.

Martin, P.Y. (2003). "Said and Done" versus "Saying and Doing": Gendering practices, practicing gender at work. Gender \& Society, 17(3), 342-366. https://doi. org/10.1177/0891243203017003002

McDowell, J. (2009). What can we learn from ADs who are Black Females? Women in Higher. Education, 18(5), 19-20.

McDowell, J., \& Cunningham, G.B. (2009). Personal, social, and organizational factors that influence black female athletic administrators' identity negotiation. Quest, 61(2), 202-222. https://doi.org/10.1080/00336297.2009.10483611

Metz, I., \& Tharenou, P. (2001). Women's career advancement: The relative contribution of human and social capital. Group \& Organization Management, 26(3), 312-342. https://doi.org/10.1177/1059601101263005

Miles, M.B., Huberman, A.M., \& Saldaña, J. (2014). Qualitative data analysis: A methods sourcebook. Thousand Oaks, CA: Sage Publications, Inc.

NACDA. (2016a). N4A mentoring program. Retrieved http://www.nacda.com/nfoura/ mentoringprogram.html

NACDA. (2016b). NAAC mentoring program. Retrieved http://www.nacda.com/sports/ naacc/spec-rel/030915aaa.html

Ohlott, P.J., Ruderman, M.N., \& McCauley, C.D. (1994). Gender differences in managers' developmental job experiences. Academy of Management Journal, 37(1), 46-67. https://doi.org/10.2307/256769

Patton, M. (2002). Qualitative research and evaluation methods. Thousand Oaks, CA: Sage Publications. 
Ragins, B.R. (1997). Diversified mentoring relationships in organizations: A power perspective. Academy of Management Review, 22, 482-521.

Ragins, B.R., \& Cotton, J.L. (1999). Mentor functions and outcomes: A comparison of men and women in formal and informal mentoring relationships. The Journal of Applied Psychology, 84(4), 529-550. PubMed https://doi.org/10.1037/0021-9010.84.4.529

Ramaswami, A., Dreher, G.F., Bretz, R., \& Wiethoff, C. (2010). Gender, mentoring, and career success: The importance of organizational context. Personnel Psychology, 63(2), 385-405. https://doi.org/10.1111/j.1744-6570.2010.01174.x

Ritchie, B.S., Fassinger, R.E., Linn, S.G., Johnson, J., Prosser, J., \& Robinson, S. (1997). Persistence, connection, and passion: A qualitative study of the career development of highly achieving African American-Black and White women. Journal of Counseling Psychology, 44(2), 133-148. https://doi.org/10.1037/0022-0167.44.2.133

Saldaña, J. (2013). The coding manual for qualitative researchers (3rd ed.). Thousand Oaks, CA: Sage Publications, Inc.

Shaw, S. (2006). Scratching the back of "Mr. X": Analyzing gendered social processes in sport organizations. Journal of Sport Management, 20(4), 510-534. https://doi. org/10.1123/jsm.20.4.510

Shaw, S., \& Frisby, W. (2006). Can gender equity be more equitable?: Promoting an alternative frame for sport management research, education, and practice. Journal of Sport Management, 20(4), 483-509. https://doi.org/10.1123/jsm.20.4.483

Singh, R., Ragins, B.R., \& Tharenou, P. (2009a). What matters most? The relative role of mentoring and career capital in career success. Journal of Vocational Behavior, 75(1), 56-67. https://doi.org/10.1016/j.jvb.2009.03.003

Singh, R., Ragins, B.R., \& Tharenou, P. (2009b). Who gets a mentor? A longitudinal assessment of the rising star hypothese. Journal of Vocational Behavior, 74(1), 11-17. https:// doi.org/10.1016/j.jvb.2008.09.009

Steward, A.D., \& Cunningham, G.B. (2015). Racial identity and its impact on job applicants. Journal of Sport Management, 29(3), 245-256. https://doi.org/10.1123/jsm.2014-0017

United States Department of Labor. (2014). Traditional and nontraditional occupations. Retrieved http://www.dol.gov/wb/stats/nontra_traditional_occupations.htm

Van Velsor, E., \& Hughes, M.W. (1990). Gender differences in the development of managers: How women managers learn from experience. Technical report no. 145, Center for Creative Leadership, Greensboro, NC.

Walker, N.A., \& Sartore-Baldwin, M.L. (2013). Hegemonic masculinity and the institutionalized bias toward women in men's collegiate basketball: What do men think? Journal of Sport Management, 27(4), 303-315. https://doi.org/10.1123/jsm.27.4.303

Weaver, M.A., \& Chelladurai, P. (2002). Mentoring in intercollegiate athletic administration. Journal of Sport Management, 16(2), 96-116. https://doi.org/10.1123/jsm.16.2.96

Whisenant, W.A., Pedersen, P.M., \& Obenour, B.L. (2002). Success and gender: Determining the rate of advancement for intercollegiate athletic directors. Sex Roles, 47(9/10), 485-491. https://doi.org/10.1023/A:1021656628604

Whitmarsh, L., Brown, D., Cooper, J., Hawkins-Rogers, Y., \& Wentworth, D.K. (2007). Choices and challenges: A qualitative exploration of professional women's career patterns. The Career Development Quarterly, 55(3), 225-236. https://doi. org/10.1002/j.2161-0045.2007.tb00079.x

Yiamouyiannis, A., \& Osborne, B. (2012). Addressing gender inequities in collegiate sport examining female leadership representation within NCAA sport governance. SAGE Open, 2(2), 1-13. https://doi.org/10.1177/2158244012449340

Young, D. (1990). Mentoring and networking: Perceptions by athletic administrators. Journal of Sport Management, 4(1), 71-79. https://doi.org/10.1123/jsm.4.1.71

Young, A.M., \& Perrewe, P.L. (2000). What did you expect? An examination of career related support and social support among mentors and protégés. Journal of Management, 26(4), 611-632. https://doi.org/10.1177/014920630002600402 